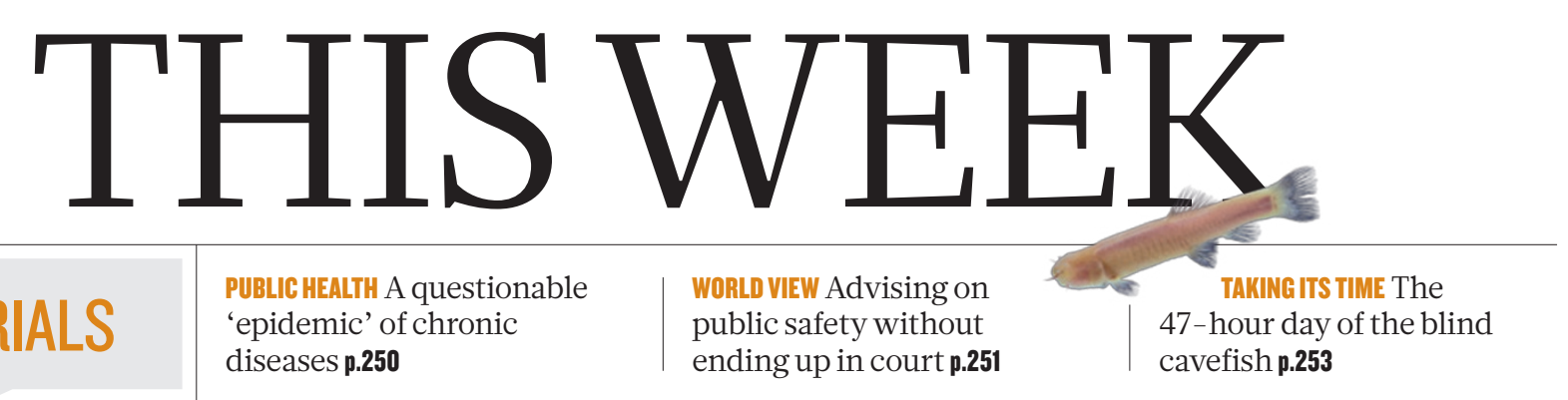

EDITORIALS diseases $\mathbf{p . 2 5 0}$ public safety without ending up in court $\mathbf{p . 2 5 1}$ 47-hour day of the blind
cavefish $\mathbf{p . 2 5 3}$

\title{
A paler shade of green
}

\author{
The Obama administration should reject the false dichotomy between environmental \\ protection and the economy.
}

$\mathrm{E}$ ven at the best of times, building political support for action on thorny environmental issues is difficult in the United States. Recent events serve as a stark reminder of what happens when times are hard. Faced with the alarming possibility of a double-dip recession and an energized opposition that has demonized environmental regulations of any kind, President Barack Obama is picking his battles carefully and seeking to carve out a middle ground on what will surely be the fundamental issue of the 2012 presidential election: the economy. Sadly, if understandably, the environment has been placed on the back burner.

An 8 September speech by Obama calling for legislation to reinvigorate a stalled economic recovery marked a striking shift from the economic stimulus bill of 2009, a time of easy rhetoric about 'green jobs. This time around, global warming didn't even get a mention and neither did clean energy, once hailed as the basis for sustainable growth and global economic competitiveness. The lamentable truth is that in the world of US politics, environmental protection is still debated as if it were an optional and expensive accessory to modern living. In the process, science is set aside.

The latest setback came on 2 September, when Obama ordered Environmental Protection Agency (EPA) administrator Lisa Jackson to stand down on tightened standards for ozone pollution. Jackson had been working to plug a hole left by the administration of former President George W. Bush, which in 2008 set weaker standards than recommended by the EPA's science advisers. Obama elected to opt out of the current rule and promised to push forward with another ozone review that is due out in 2013.

The idea that tightening ozone standards would damage the economy is questionable at best. Numerous studies have shown that pollution control tends to pay for itself by reducing public-health bills; moreover, money spent on reducing emissions does not disappear into a vacuum: pollution control is a business, too. In backing off from the tighter regulations, Obama was looking to disarm his political opponents more than anything else, but in doing so he lent false legitimacy to the misguided debate that pits the economy against public health and environmental protection.

The Obama administration has also been cautious in extending its regulatory powers to the overwhelming environmental issue of our time, climate change. Yet regulation based on existing laws is the only remaining tool for addressing the issue now that greenhouse-gas legislation is off the table. A proposed pipeline from the Canadian tar sands in Alberta to US refineries along the Gulf of Mexico has become the latest flashpoint for disputes over climate policy. Activists say that the pipe will accelerate the extraction of oil from the tar sands, and hundreds of people - including NASA climate scientist James Hansen - were arrested at protests staged at the White House in late August.

Final word on the Keystone XL pipeline rests with the Department of State, which issued an environmental-impact statement on the

project last month and is widely expected to approve the project this autumn. In fact, the pipeline protests say more about the sorry state of the environmental agenda than anything else. It is true that greenhouse-gas emissions from oil extracted from the sands are $15-20 \%$ higher than those from average crude oil if assessed on a life-cycle

\section{"Money spent} on reducing emissions does not disappear into a vacuum." basis, but industry officials are correct in pointing out that this is on a par with other dirty oils produced in the United States and elsewhere using steam injection. And halting this pipeline is unlikely to halt development of the tar sands or other dirty sources of energy. What is missing, now as ever, is a policy to address the larger climate threat.

Science-based regulation may yet have a chance. The EPA will soon propose regulations that would reduce emissions of mercury and other pollutants from power plants and other industrial sources. In his address to Congress, Obama insisted that the economic crisis should not be used as an excuse to wipe out basic economic, health and environmental protections. "We shouldn't be in a race to the bottom," Obama said, "where we try to offer the cheapest labour and the worst pollution standards." Obama and his administration still have the opportunity to live up to those words.

\section{Patent medicine}

\section{A simplification of the US patent system is good news for inventors, but could have gone further.}

\section{$\mathrm{T}$} The passage of a patent-reform bill by the US Senate on 8 September was a rare win for President Barack Obama, who on the same day gave a high-profile speech on job creation and argued that patent reform was part of the solution. The America Invents Act, as it is called, is also good news for researchers and their institutions.

The link to jobs is speculative, but the bill is likely to simplify life for inventors. Most significantly, it moves the United States to a firstto-file system, in which patents are granted to those who get their applications to the patent office first. That should eliminate the lengthy administrative procedures that are often required to determine who has the true priority on inventions under the current first-to-invent system. Any scientist who has ever been caught up in a patent wrangle - such as the competition between Bell Laboratories and IBM for the US patent on the high-temperature superconductor yttrium barium copper oxide, which famously took 13 years to be settled in favour of Bell Labs - will see the advantages of that. 